ANDRÉ GARCIA XEREZ SILVA

\title{
A TOLERÂNCIA NO PROCESSO ELEITORAL BRASILEIRO: CONTORNOS JURÍDICOS E PERSPECTIVAS
}

\author{
Tese de Doutorado
}

Orientadora: Profa. Dra. Monica Herman Salem Caggiano

UNIVERSIDADE DE SÃO PAULO

FACULDADE DE DIREITO

SÃO PAULO

2020 



\title{
A TOLERÂNCIA NO PROCESSO ELEITORAL BRASILEIRO: CONTORNOS JURÍDICOS E PERSPECTIVAS
}

\begin{abstract}
Tese apresentada a Banca Examinadora do Programa de Pós-Graduação em Direito, da Faculdade de direito da Universidade de são Paulo, como exigência parcial para obtenção do título de Doutor em Direito, na área de concentração Direito do Estado, sob a orientação da Profa. Dra. Monica Herman Salem Caggiano.
\end{abstract}

UNIVERSIDADE DE SÃO PAULO

FACULDADE DE DIREITO

SÃO PAULO

2020 
Garcia Xerez Silva, André

A tolerância no processo eleitoral brasileiro: contornos jurídicos e perspectivas ; André Garcia Xerez Silva; orientadora Monica Salem Herman Caggiano -- São Paulo, 2020.

272

Tese (Doutorado - Programa de Pós-Graduação em Direito do Estado) - Faculdade de Direito, Universidade de São Paulo, 2020.

1. Tolerância. 2. Processo eleitoral. 3. Jurisdição eleitoral. 4. Democracia. I. Salem Herman Caggiano , Monica, orient. II. Título. 


\section{A TOLERÂNCIA NO PROCESSO ELEITORAL BRASILEIRO: CONTORNOS JURÍDICOS E PERSPECTIVAS}

Tese apresentada ao Programa de PósGraduação em Direito de Estado, como requisito para obtenção do título de Doutor em Direito do Estado.

Orientadora: Prof. ${ }^{\text {a }}$ Dr. ${ }^{\text {a }}$ Monica Herman Salem Caggiano. 

A todos os seres humanos, para manter viva a lembrança do atributo que assim lhes define e une: sua humanidade. 



\section{AGRADECIMENTOS}

Receio que redigir os agradecimentos na medida e na justiça devida a todas as pessoas que contribuíram nesta empreitada ultrapassaria em extensão o texto da própria tese, certamente inviabilizando sua apresentação e tornando inócuo tal esforço, o que me obriga exercer o máximo poder de síntese ao qual já me submeti. Foram anos de renúncias, sacrifícios, incontáveis vôos de Fortaleza pra São Paulo e, acima de tudo, muito aprendizado no universo acadêmico propiciado pela tradicional e prestigiada Universidade de São Paulo.

Logo após concluir meu mestrado em 2014, estava decidido a não interromper a jornada investigativa pela busca de conhecimento, quando, de imediato, comecei a avaliar as condições e a viabilidade para cogitar me aventurar no processo seletivo do maior Programa de Pós Graduação em Direito do país. Estimulado pelo então chefe, hoje sócio, Dr. Hélio Parente, e sempre orientado pelo Prof. Dr. Martonio Mont'Alverne Barreto Lima, fui aprovado no início de 2015, como aluno especial, na disciplina "Princípios do Direito Eleitoral na jurisprudência do TSE e STF, ministrada pela Profa. Dra. Monica Herman Salem Caggiano, que futuramente me honraria com sua valiosa orientação.

Para assistir as aulas durante aquele semestre, que aconteciam todas as segundas-feiras, às $9 \mathrm{~h}$ da manhã, embarcava em um vôo semanal que partia $3 \mathrm{~h}$ da madrugada e pousava em torno de $6 \mathrm{~h} 30$ em Guarulhos, de onde eu seguia direto para a Faculdade de Direito e retornava no final de dia para Fortaleza após o curso. Meu primo Yuri, operosa e voluntariamente, saia de casa e me levava para o aeroporto todas as madrugadas de segunda-feira, pelo simples motivo de acreditar na minha formação e capacidade para oferecer alguma contribuição à sociedade, a quem cabe essa explícita e humilde expressão de gratidão, por um gesto que talvez pareça pequeno, mas que, para mim, sempre foi de gigantesca importância.

A logística para o doutorado também rendeu um dos maiores legados que eu pretendo preservar por muito tempo. Ricardo Grillo, amigo de primeira hora, de maneira completamente espontânea e unilateral, abrigou-me em São Paulo durante essa jornada em sua residência. Não é exagerado dizer que fui realmente adotado por ele, que gentilmente não só me transportava para meus compromissos acadêmicos, mas também os assistia quando tinha a oportunidade. A convivência nesse período presenteou-me com o estreitamento dos nossos laços de amizade e, principalmente, com muito aprendizado diante da oportunidade de 
testemunhar a nobreza de seu caráter, que, a despeito das agruras do tempo, jamais perdeu a leveza e a capacidade de acreditar nas pessoas.

Com a aprovação no processo seletivo para aluno regular do Programa, iniciou-se uma nova etapa de engajamento e compromisso com todas as obrigações acadêmicas decorrentes das graves responsabilidades que acarretam o percurso para a titulação pretendida. Indubitavelmente, a liderança e orientação da Prof. Dra. Monica Caggiano foi decisiva para que fosse possível concluir esta saga da maneira enriquecedora como foi. Lúcida, serena, técnica, sem jamais abandonar o rigor científico no manuseio dos conceitos jurídicos, seu olhar criterioso e cirúrgico permitiu que se desenvolvessem as reflexões necessárias para submeter à comunidade científica a presente investigação. Na esteira de seu rigor conceitual, sei que não há palavra no vocabulário português com a fidelidade semântica necessária para exprimir a real envergadura do sentimento de gratidão a qual eu possa recorrer no momento para agradecer à Professora Monica por haver confiado e acreditado em mim, desde quando fui seu aluno especial até a última revisão deste trabalho. Espero haver minimamente correspondido e, quem sabe, colaborado para sua incansável e intransigente defesa da democracia.

A inteligência e perspicácia do Prof. Dr. Cláudio Salvador Lembo é um privilégio que me foi oportunizado desfrutar nas aulas ministradas pela Professora Monica Caggiano. Bem humorado e arguto em suas provocações, o Professor Lembo sempre ofereceu uma visão crítica da realidade na contramão de modelos dogmáticos estrangeiros que se costumam importar na tentativa de explicar, sem sucesso, os problemas brasileiros. Foi uma honra conviver com tamanho intelecto, agora também emprestado para esta banca de doutorado.

Os conterrâneos, Prof. Dr. Martonio Mont'Alverne Barreto Lima e Profa. Dra. Raquel Cavalcanti Ramos Machado aceitaram o convite para abandonar provisoriamente nosso Ceará a fim de participar desta solene ocasião de avaliação crítica do meu estudo, a quem agradeço, desde já, tanto pela pronta aceitação do convite, quanto pelas produções acadêmicas que subsidiaram esta pesquisa.

O desafio é proporcional à credibilidade dos nomes do Prof. Dr. Gilberto Bercovici e Prof. Dr. Carlos Bastide Horbach, que personificam a grandeza e a autoridade intelectual que a Universidade de São Paulo representa na comunidade acadêmica, a quem também agradeço a oportunidade de submeter minhas inquietações a intelectuais de tamanha expressão. 
À minha família, cuja definição se materializa no apoio que irrestritamente me foi ofertado, é necessário reiterar o sentimento de gratidão aos meus pais, Adrienne e João Júnior, por quem eu sempre lutei para superar os percalços vida. Meus avós maternos, Jeanne e Adriano, continuam alimentando doçura na minha vida, verdadeiro combustível para enfrentar todos os obstáculos. Meus avós paternos, Diana, hoje presente em memória, e João Silva, são exemplos de entrega e carinho absoluto, dos quais pude me acalentar.

Minha namorada, Roberta, esteve presente ao meu lado em todas as etapas percorridas até este momento, desde a aprovação no exame de proficiência em língua estrangeira no processo seletivo, testemunhando meu nervosismo ao conferir o gabarito, até os silenciosos dias em que eu precisava me concentrar para tentar exercer uma profícua produção intelectual à altura deste Programa. Seu companheirismo, carinho e compreensão também são autores desta tese e estão grafados nas letras e ideias aqui reproduzidas, ainda que, em razão das formalidades acadêmicas, não constem nas notas de rodapé.

Os meus colegas do Programa dividiram aflições parecidas de modo a nos ajudarmos mutuamente. Alessandra Sales, Glauco Costa Leite, Nicanor Komata e Lucas Verdero foram fundamentais interlocutores no encurtamento da distância entre Fortaleza e São Paulo na condução de todas as atividades acadêmicas e administrativas, além de serem competentes profissionais dos quais pude apreender e assimilar enriquecedoras reflexões.

Finalmente, Natalia Tammone aceitou revisar minha pesquisa, oportunidade em que me foram revelados ajustes importantes e necessários na correção de "pontos cegos" quando a exaustão manifestava seus primeiros sinais. Seu rigor científico elevou esta pesquisa aos padrões oficiais qualificadores da credibilidade da pesquisa acadêmica, pelo que são dignos de nota e merecida gratidão os seus esforços prestados.

Atravessar um curso de Doutorado em Direito na Universidade de São Paulo é um degrau que me afigurava intangível sob vários aspectos. A conclusão desta jornada representa a superação de etapas no tempo e modo que não poderiam hoje parecer mais acertados. Submeti-me ao vestibular para ingressar no curso de Direito em 2006 na Universidade de Fortaleza, na Universidade Federal do Ceará e Universidade de São Paulo. Naquela época, fui aprovado apenas na UNIFOR, onde conclui minha graduação em 2012, ano no qual também fui aprovado para o Mestrado da Universidade Federal do Ceará, obtendo a titulação de Mestre em 2014. Eis que agora o ápice da minha vida acadêmica se encerra onde um dia se fechou uma porta na minha vida. Espero que todos os anos de investigação e pesquisa 
acumulados façam jus ao protagonismo intelectual dos egressos desta Universidade de São Paulo e, sobretudo, que esta tese seja capaz de contribuir com o aprimoramento da Ciência Jurídica, de nossas instituições e fortaleça, cada vez mais, a crença nos valores democráticos para a preservação de toda a beleza e riqueza da vida que repousa na diversidade humana. 
"Are there any queers in the theatre tonight?

Get 'em up against the wall!

Now that one in the spotlight, he don't look right to me

Get him up against the wall!

That one looks Jewish!

And that one's a coon!

Who let all this riff-raff into the room?

There's one smoking a joint!

And another with spots!

If I had my way I'd have all of you shot!"

(Pink Floyd - In The Flesh). 



\section{RESUMO}

Este trabalho problematiza uma possível retração dos regimes democráticos na contemporaneidade em face da ascensão de diversas expressões de intolerância entre os indivíduos na sociedade e o enfrentamento desse fenômeno pela jurisdição eleitoral brasileira. A fim de assegurar a subsistência e longevidade do regime democrático, procura-se assentar a tolerância como elemento teórico fundamental da democracia, com base no estudo de obras clássicas e modernas da Filosofia, Ciência Política e Jurídica, de modo a revelar a essencialidade do conceito como indicador de qualidade democrática. Em seguida, pretende-se demonstrar os reflexos da intolerância na corrosão do tecido social que conduzem à fragilização e ruína da democracia. Para tanto, procede-se ao exame histórico dos principais aspectos políticos e jurídicos da realidade estrangeira vivenciada pelo Nacional Socialismo alemão, enquanto emblemática e sofisticada experiência da conformação estatal e institucional à perseguição de grupos marginalizados social e juridicamente, e se analisa a realidade brasileira a partir do exame das consequências de sua colonização e da formação de uma cultura de violência, além do enfrentamento crítico do julgamento do Habeas Corpus n. 82.424 pelo Supremo Tribunal Federal. Por fim, na condição de instituição indispensável à garantia da democracia brasileira, situa-se a Justiça Eleitoral como protagonista na defesa da regularidade e legitimidade do processo eleitoral. Investiga-se criticamente o conjunto da legislação que compõe a grade de proteção normativa da tolerância no embate eleitoral no que diz respeito ao regime jurídico dos partidos políticos, propaganda eleitoral, inelegibilidades e abuso de poder nas eleições, a fim de propor categorias analíticas e conceitos jurídicos capazes de aperfeiçoar o controle judicial exercido pela Justiça Eleitoral destinado a inibir condutas que incitam à propagação da intolerância de maneira a fortalecer os postulados da democracia.

Palavras-chave: TOLERÂNCIA; PROCESSO ELEITORAL; JURISDIÇÃO ELEITORAL; DEMOCRACIA. 


\begin{abstract}
This research problematizes a possible retraction of democratic regimes in contemporary times due to the rise of various expressions of intolerance among individuals in society and the confrontation of this phenomenon by the brazilian electoral jurisdiction. To ensure the subsistence and longevity of the democratic regime, it seeks to establish tolerance as a fundamental theoretical element of democracy, based on the study of classical and modern works of philosophy, political science and law, in order to reveal the essentiality of the concept as an indicator of democratic quality. Then, it is intended to demonstrate the reflections of intolerance in the corrosion of the social contexture that lead to the weakening and ruin of democracy. To this end, a historical examination of the main political and legal aspects of the foreign reality experienced by the German National Socialism is performed as an emblematic and sophisticated experience of state and institutional conformation to the persecution of socially and legally marginalized groups, and the brazilian reality is analyzed from the study of the consequences of its colonization and the formation of a culture of violence, besides the critical analysis of the judgment of Habeas Corpus. 82.424 by the Federal Supreme Court. Finally, as an indispensable institution for the guarantee of Brazilian democracy, the Electoral Justice is situated as a protagonist in the defense of the regularity and legitimacy of the electoral process. The legislation set that makes up the normative protection grid of tolerance in the electoral dispute with regard to the juridical regime of political parties, electoral propaganda and and abuse of power in the elections is critically examined, in order to propose analytical categories and juridical concepts capable to enhancing the judicial control exercised by the Electoral Justice to inhibit behaviors that encourages the spread of intolerance in order to fortify the postulates of democracy.
\end{abstract}

Keywords: TOLERANCE; ELECTORAL PROCESS; ELECTORAL JURISDICTION; DEMOCRACY. 


\section{SUMÁRIO}

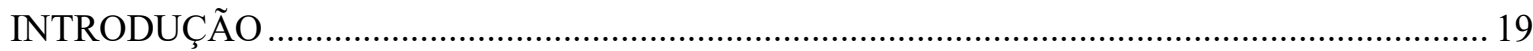

1. TOLERÂNCIA COMO FUNDAMENTO DA DEMOCRACIA …................................................ 27

1.1 A coletivização dos afetos e a potência da multidão em Espinosa ..........................................2 29

1.2 A dualidade formal e material da democracia: procedimentalismo ou substancialismo? ...... 43

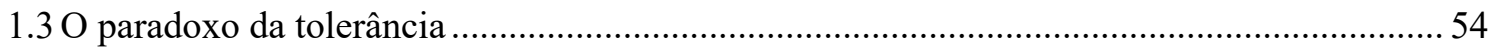

1.4 Tutela jurídica das minorias e oposição na política ................................................................. 71

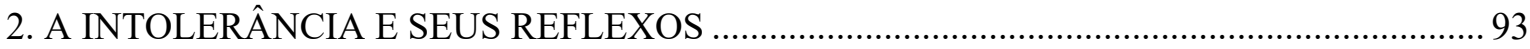

2.1 A ascensão do Nacional Socialismo: principais aspectos políticos e jurídicos ........................94

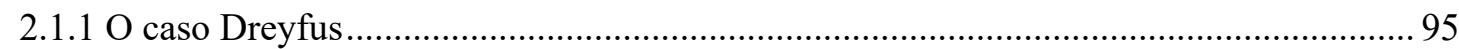

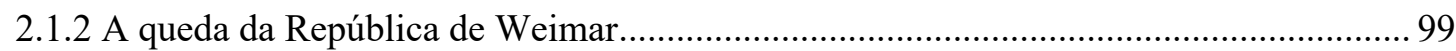

2.1.3 A trajetória e as consequências de Hitler para a democracia......................................... 106

2.2 Violência e intolerância na formação brasileira ...................................................................... 121

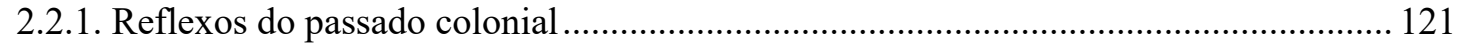

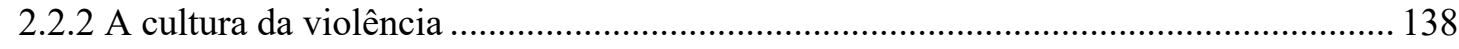

2.2.3 O julgamento de Siegfried Ellwanger pelo Supremo Tribunal Federal......................... 150

3. A PROTEÇÃO JURÍDICA DA TOLERÂNCIA NO PROCESSO ELEITORAL BRASILEIRO

3.1 Justiça Eleitoral como instituição garantidora da democracia ............................................ 173

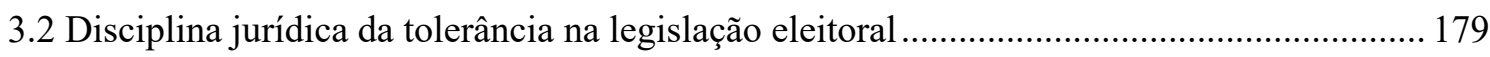

3.2.1 Registro, funcionamento e cassação dos partidos políticos ........................................... 180

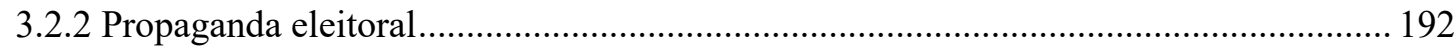

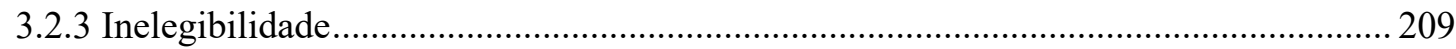

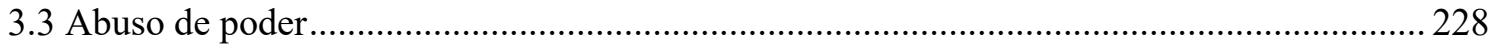

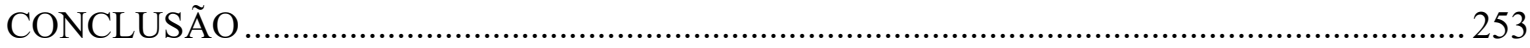

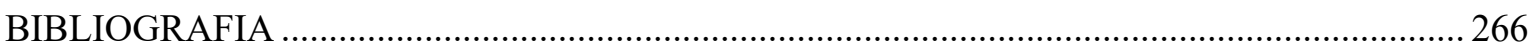





\section{INTRODUÇÃO}

A história da democracia não foi sempre linear e progressiva na direção de sua expansão e aprimoramento. Ao contrário, o que se percebe é um movimento pendular, próprio da dialética dos conflitos e contradições históricas que a luta por um regime de governo como a democracia encerra. Quem parece oferecer a melhor radiografia desse movimento é Samuel Huntington, ao catalogar as ondas de democratização que foram sucedidas por ondas reversas, considerando as transições entre governos democráticos e não democráticos por meio de um estudo descritivo de cada realidade nacional.

A primeira onda, longa, de democratização, com raízes nas revoluções americana e francesa, manifestou-se nos anos de 1828 a 1926. A primeira onda reversa começou em 1922, com a marcha para Roma e o controle da frágil democracia italiana por Mussolini, passando pela conquista do poder por Hitler em 1933, encerrando-se em 1942. A segunda onda, curta, de democratização se estendeu de 1943 a 1962, período marcado pela influência do final da Segunda Guerra Mundial, que promoveu a inauguração de instituições democráticas na Alemanha Ocidental, Itália, Áustria, Japão, Coréia, Europa, além de Uruguai, Brasil, Costa Rica, Argentina, Colômbia, Peru e Venezuela, na América Latina. A segunda onda reversa, situada de 1958 a 1975, marcou a instalação de regimes militares, sobretudo na América Latina, mas também na Ásia (Paquistão, Coréia, Indonésia, Filipinas e Taiwan) e no Mediterrâneo (Grécia e Turquia). Finalmente, a terceira onda de democratização iniciou-se em 1974, com a Revolução dos Cravos em Portugal, seguindo-se pelos 15 anos subsequentes, com a substituição de regimes autoritários por democráticos em aproximadamente 30 países da Europa, Ásia e América Latina, além de uma considerável liberalização em regimes autoritários na África e no Oriente Médio ${ }^{1}$.

O estudo de Huntington, publicado em 1994, indica um padrão de expansão e retração das democracias nada alvissareiro para o futuro da democracia na atual quadra histórica, considerando, caso ele esteja correto, que a próxima etapa do movimento será fatalmente uma terceira onda reversa contra a onda de democratização iniciada em 1974. A

\footnotetext{
${ }^{1}$ HUNTINGTON, Samuel P. A terceira onda: a democratização do século XX. Tradução de Sergio Gois de Paula). Ática: São Paulo, 1994, p. 25.
} 
consagração da democracia no século XXI não parece ser suficiente para garantir sua sobrevivência e longevidade de maneira irreversível.

Diversos acontecimentos recentes mundo afora revelam uma aparente ascensão do sentimento de ódio e intolerância nas sociedades contemporâneas, culminando com ações violentas contra determinados grupos, motivadas por uma (ir)racionalidade política, étnica, ideológica, religiosa ou sexual. A gravidade do que a convivência social vem experimentando merece ser encarada racionalmente para examinar com lucidez a complexidade dos desafios com os quais os governos e as sociedades modernas se deparam. Há uma inevitabilidade do enfraquecimento e esgotamento dos regimes democráticos naturalmente com o curso do tempo? É possível que a ciência do Direito enfrente uma onda reversa de democratização a ponto de evitá-la ou, pelo menos, mitigála? O que o Estado e a política podem fazer na intermediação dos conflitos que são inerentes à democracia, mas que, em determinada medida, podem arruiná-la? A democracia conforma-se a manifestações de intolerância, até certo ponto, indissociáveis do convívio entre diferentes indivíduos? Qual controle pode ser exercido contra a disseminação da intolerância, especificamente no âmbito do processo eleitoral brasileiro? Interessa ao Direito se ocupar dessas questões?

Essas reflexões não recomendam uma compreensão isolada de episódios que atentem contra o constitucionalismo democrático. A consciência universal assimilou com profundo espanto o terror provocado pela Segunda Guerra Mundial, que divisou a história e obrigou repensar os rumos e o papel das instituições que governam as sociedades.

É inquietante a narração de Hannah Arendt sobre o julgamento de Eichmann, que, mesmo tendo afirmado aos seus homens nos últimos dias de guerra: "eu vou dançar no meu túmulo, rindo, porque a morte de 5 milhões de judeus [...] na consciência me dá enorme satisfação"2, declarou-se perante a Corte Distrital de Jerusalém "inocente, no sentido da acusação"3. À medida que Eichmann era ouvido sobre declarações como a de que "teria mandado seu próprio pai para a morte se isso tivesse exigido" ${ }^{4}$, percebia-se que não se estava diante de um monstro, mas de alguém completamente incapaz de pensar sob

\footnotetext{
2 ARENDT, Hannah. Eichmann em Jerusalém: um relato sobre a banalidade do mal. São Paulo: Companhia das Letras, 1999, p. 59.

${ }^{3}$ Ibidem, p. 32.

${ }^{4}$ Ibidem, p. 54.
} 
o ponto de vista de outra pessoa e para além de toda a burocracia alienante da função que ocupava.

Com o espólio da Segunda Guerra, o constitucionalismo ingressou em uma nova fase: a tentativa da cultura de direitos humanos sobreveio como resposta ao aprendizado decorrente desse genocídio. O papel do Direito e das instituições redefiniu-se em favor de um pensamento que ofertasse uma tutela de proteção mínima ao cidadão que garantisse sua existência digna em vários aspectos. Róis de direitos fundamentais foram encartados pelas constituições e, sem uma nova grande guerra, o mundo experimentou relativa estabilidade, pelo menos em relação ao abismo degradante do qual acabava de começar a se recuperar.

Apesar da transformação causada pelos impactos da Segunda Guerra e o despertar para uma preocupação mais sensível com a ascensão de novos regimes antidemocráticos, a literatura remonta episódios anteriores ao século XX, que retratam a corrosão do tecido social causado pelo sentimento antissemita, já no século XVI, na obra de Shakespeare. Em O Mercador de Veneza, o escritor expressa o comovente desabafo enfurecido de Shylock, um rico judeu, ao tentar ser dissuadido de cobrar um pedaço de carne do cristão que lhe estava em débito, segundo fora pactuado:

\footnotetext{
Sou um judeu. Então, um judeu não possui olhos? Um judeu não possui mãos, órgãos, dimensões, sentidos, afeições, paixões? Não é alimentado pelos mesmos alimentos, ferido com as mesmas armas, sujeito às mesmas doenças, curado pelos mesmos meios, aquecido e esfriado pelo mesmo verão e pelo mesmo inverno que um cristão? Se nos picais, não sangramos? Se nos fazeis cócegas, não rimos? Se nos envenenais, não morremos? E se vós nos ultrajais, não nos vingamos? Se somos como vós quanto ao resto, somos semelhantes também nisto ${ }^{5}$.
}

Tom Holland busca explicações no avanço do Império persa contra a resistência grega, em 480 A.C., pois "se os gregos tivessem sido subjugados pela invasão de Xerxes,

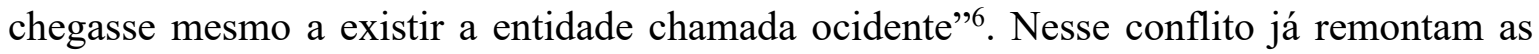
primeiras raízes de conceitos como "o monoteísmo e a noção de um Estado universal, democracia e totalitarismo: tudo isso pode ter suas origens traçadas remontando ao período das Guerras Persas" 7.

\footnotetext{
${ }^{5}$ SHAKESPEARE, William. O mercador de Veneza. 2. ed. São Paulo: Martin Claret, 2013, pp. 69-70.

${ }^{6}$ HOLLAND, Tom. Fogo persa. Rio de Janeiro: Record, 2008, p. 17.

${ }^{7}$ Ibidem, p. 21.
} 
Assim, analisar os principais acontecimentos e fenômenos que revelam os caminhos do pensamento constitucional e político na edificação da tolerância como elemento necessário ao regime democrático, com ênfase na modernidade, é tarefa que, a par da preocupação humanitária com o destino da sociedade, merece investigação acadêmica no plano do Direito do Estado, pois lhe incumbe diretamente a (re)formulação do pacto social para refletir as perspectivas de um constitucionalismo democrático na modernidade, que se propõe a ser examinado no curso deste estudo sob a ótica dos instrumentos jurídicos à disposição da legislação brasileira para coibir a disseminação da intolerância durante o processo eleitoral. Portanto, o estudo e a definição da democracia como forma de governo e de representação política precisa se perguntar a que se devem os novos impulsos contrários à democracia que voltam a frequentar a cena política.

A preocupação deve ser transposta para a atualidade e a aparente normalidade democrática, visto que, conforme adverte Monica Caggiano ${ }^{8}$, "o processo eleitoral para a seleção de governantes/representantes não é, todavia, exclusividade da democracia, mas é utilizado, com características e tonalidades diversas, até mesmo sob regimes autoritários e totalitários". Da observação desse sintoma, a pensadora denuncia a insuficiência da mecânica eleitoral para identificação do regime político, bem como revela que o sufrágio "não é garantia da efetiva concretização do princípio representativo" ". Por isso, é evidente a necessidade de se recorrer ao Direito do Estado para a investigação que se planeja.

O diagnóstico de Jacques Rancière sugere que, em virtude da lógica democrática que subverte a ordem natural de títulos que orienta as relações sociais, democracia pode significar, nessa perspectiva, "um governo anárquico, fundamentado em nada mais do que na ausência de qualquer título para governar" ${ }^{\prime 10}$. Daí por que não é difícil concluir que o "governo de qualquer um está fadado ao ódio infindável de todos aqueles que têm de apresentar títulos para o governo dos homens: nascimento, riqueza ou ciência"11.

Interligar essas questões à luz do papel do Direito e do Estado sugere uma análise filosófica, social, jurídica e política da intolerância na modernidade como ameaça ao caminhar democrático da humanidade. Para a subsistência da democracia, a tolerância é um de seus fundamentos indispensáveis sobre o qual se assenta o regime, que merece ser

${ }^{8}$ CAGGIANO, Monica Herman Salem. Direito parlamentar e direito eleitoral. Barueri: Manole, 2004, p. 75 .

${ }^{9}$ Ibidem, p. 76.

${ }^{10}$ RANCIÈRE, Jacques. O ódio à democracia. São Paulo: Boitempo, 2014, p. 57.

${ }^{11}$ Ibidem, p. 119. 
particular tutela jurídica, especialmente durante o curso do processo eleitoral, na medida em que consiste no ápice do florescimento e da mobilização dos conflitos políticos e de ideias, a partir do qual a legitimidade do voto poderá vir a fundamentar a ideologia defendida do candidato vitorioso nas urnas, além de a via eleitoral ser o canal pelo qual as rupturas democráticas atualmente se desenvolvem.

Para finalidade deste trabalho e a fim de manter sua centralidade teórica, os autores aqui referenciados servirão de suporte para o olhar a ser lançado no constitucionalismo democrático brasileiro e suas perspectivas após 1988. Esse referencial teórico inicial delimitará as reflexões a serem aprofundadas e desenvolvidas, visando a analisar a tolerância enquanto elemento necessário ao regime democrático, os reflexos da ascensão da intolerância para o Estado Democrático de Direito e os desafios que o Direito deverá cumprir na consolidação da democracia no que diz respeito ao aparato jurídico que regulamenta o processo eleitoral brasileiro na inibição de manifestações de ódio.

Partindo dos termos acimas problematizados acerca do objeto em estudo, serão examinadas, inicialmente, as premissas filosóficas, políticas e jurídicas que permitem argumentar que a tolerância representa um dos fundamentos da democracia. Para tanto, examinar-se-á a contribuição do pensamento filosófico de Baruch de Espinosa na conformação das relações do indivíduo com a sociedade com base nos principais conceitos de sua obra. Procurar-se-á problematizar as dimensões formal e material de democracia sob a ótica de proteção das diferenças, bem como analisar a aparente contradição decorrente do paradoxo da tolerância quanto aos controversos limites da convivência com intolerância e se apresentará a importância constitucional da tutela jurídica das minorias e da oposição na política na edificação desta ideia.

Em seguida, serão demonstrados os reflexos da intolerância na corrosão do tecido social até a ruína do governo democrático. Em que pese a vasta extensão de experiências globais de regimes institucionais antidemocráticos, dada a sua relevância e sofisticação de funcionamento baseada na mais emblemática expressão de ódio e intolerância universal, cujo contexto social, político e jurídico que levou à falência da democracia, ascensão do Nacional Socialismo na Alemanha afigurar-se-á etapa intelectual necessária a ser percorrida. Não obstante, não haveria como descurar do cenário local para complementar a visão colhida na experiência estrangeira, a fim de descontruir uma mitologia romântica de uma relativa facilidade na integração cultural dos diversos segmentos que compõem a 
sociedade brasileira, motivo pelo qual a realidade nacional merecerá ocupar espaço nesta reflexão, por meio do exame das consequências de nossas raízes coloniais, uma proposta de compreensão da institucionalização de uma cultura da violência e o enfrentamento crítico do julgamento do Habeas Corpus n. 82.424-2 pelo Supremo Tribunal Federal, que ficou conhecido como caso "Siegfried Ellwanger".

Percorridas essas premissas, será dissecada a legislação brasileira que regula a lisura e legitimidade do processo eleitoral brasileiro e suas interseções com a tutela jurídica da tolerância. Há um plexo normativo esparso que atravessa diversos temas relacionados à disciplina dos partidos políticos, propaganda eleitoral, inelegibilidades e abuso de poder, que se pretende examinar sob a ótica do âmbito de proteção da tolerância, assegurada sob diversos aspectos no embate eleitoral.

A criação da Justiça Eleitoral deverá ser compreendida, assim, antes de tudo, como instituição destinada a garantir o pleno funcionamento da democracia. É no âmbito de sua jurisdição que os conflitos decorrentes por mandatos eletivos se resolvem e a seus integrantes cabe oferecer as diretrizes e parâmetros de controle que impactarão na conduta dos candidatos. Além de sua função jurisdicional, no exercício de sua função administrativa e normativa, esta Justiça Especializada do Poder Judiciário desempenha papel decisivo na consolidação da democracia e na proteção de seus postulados. Por isso, o curso do processo eleitoral com os conflitos que lhes são inerentes foi delimitado como o fenômeno jurídico sensível a ser dissecado no que se refere à análise crítica da grade de proteção da tolerância, uma vez que lhe caberá, em última instância, chancelar e atestar a legalidade do mandato eletivo conferido com base na expressão popular à luz dos ditames constitucionais.

Conforme percebeu Dahl ${ }^{12}$, as variações no sistema constitucional não interferem diretamente na consolidação das principais democracias maduras do mundo, pois sua promoção depende mais da crença e cultura compartilhada pela elite política, jurídica e cultural. Reforça essa compreensão Dworkin ${ }^{13}$, para quem a democracia não será saudável com uma profunda e ácida divisão e sem argumentos verdadeiros, porque se tornaria apenas uma tirania de números.

${ }^{12}$ DAHL, Robert. How democratic is the American constitution? 2. ed. Yale: Yale University Press, 2003, p. 99.

${ }^{13}$ DWORKIN, Ronald. Is democracy possible here?: principles for a new political debate. Princeton: Princeton University Press, 2008, p. 6. 
O papel do Direito na mediação dos conflitos sociais que ameaçam a sobrevivência democrática é tarefa iminente, diante da necessidade de se evitar, ou, pelo menos, mitigar, uma nova retração democrática cujas consequências o mundo testemunhou em um passado não tão distante. A ciência jurídica deve assimilar uma abordagem interdisciplinar a fim de trazer para seu objeto de estudo fatos sociais que dialoguem com o fenômeno jurídico, o que justifica esta tese, como reflexão destinada à compreensão da nova fase de desafios que afligem o constitucionalismo democrático no âmbito do processo eleitoral brasileiro.

A originalidade do projeto de tese está diretamente relacionada à especificidade da situação vivenciada no Brasil e no mundo. Ainda que se localizem muitos estudos na literatura jurídica sobre democracia, pouco ainda tem se teorizado a respeito da nova realidade política, que desafia as atuais ordens democráticas a provarem perante a História sua plena consolidação, motivo pelo qual se propõe examinar como pode a democracia resistir aos novos impulsos antidemocráticos da modernidade por meio do investigação científica da proteção jurídica da tolerância na legislação eleitoral brasileira. Além disso, pretende-se oferecer uma releitura crítica das normas que interferem na defesa da tolerância a fim de sugerir categorias analíticas e conceitos interpretativos sobre a grade de proteção democrática brasileira capazes de abranger a realidade estudada com base nos clássicos e modernos pensamentos da literatura sobre o tema.

Não se trata de revisão de discussão acumulada no pensamento jurídico. O que se pretende é um olhar científico sobre o "estado da arte" na filosofia e teoria política, a partir do acúmulo que se construiu e da ação concreta da política (por meio de decisões, legislação, ações de partidos e representantes dos setores sociais) na experiência estrangeira, no Brasil e, sobretudo, na legislação eleitoral brasileira relacionada à tutela da tolerância. A abordagem se propõe interdisciplinar quanto aos influxos antidemocráticos sob aspectos sociais e políticos à luz das teorias contemporâneas de democracia, sem prejuízo da remissão a obras clássicas da Ciência Política.

No julgamento do Habeas Corpus n. 82.424-2 em 2003, o Supremo Tribunal Federal delineou os primeiros contornos da resposta institucional em um ambiente democrático, diante de demonstrações de intolerância que flertavam com o totalitarismo. Porém, por cuidar de uma compreensão ainda incipiente e não consolidada na literatura jurídica, a tese que se pretende desenvolver é inédita na tentativa de identificar se o atual regime democrático, com base nas normas destinadas a tutelar a tolerância no processo 
eleitoral brasileiro, é suficiente para garantir sua sobrevivência em face do acirramento das disputas sociais, por meio do papel do Estado Democrático de Direito na institucionalização da tolerância como fundamento e pressuposto da democracia.

A experiência universal sobre a perversidade dos regimes autoritários e totalitários que ascenderam no século XX precisa ser revisitada para que a ciência jurídica não descuide de se ocupar dos iminentes confrontos que ressuscitam agora no século XXI em sociedades democráticas a fim de oferecer mecanismos jurídicos de contenção dos impulsos antidemocráticos.

A presente tese insere-se, pois, no programa do Curso de Doutorado em Direito do Estado da Universidade de São Paulo, na Área de Concentração de Direito do Estado, na Subárea de Direito Constitucional, especificamente na linha de pesquisa: "Direitos fundamentais, democracia e limitação do poder”. Procurar-se-á examinar os motivos pelos quais a tolerância poderia se apresentar como fundamento da democracia, para, em seguida, analisar os reflexos da intolerância da modernidade, que subsiste nos atuais regimes democráticos, a despeito da consagração filosófica e política no século XXI do constitucionalismo democrático, de modo a, enfim, investigar criticamente a grade normativa do processo eleitoral brasileiro destinada à tutela da tolerância a fim de se apontar propostas interpretativas e conceitos jurídicos para fortalecer a defesa da democracia. Na consecução desta pesquisa será utilizada a técnica monográfica, utilizando como ferramentas os artigos, livros e decisões judiciais consultados. A pesquisa terá natureza predominantemente bibliográfica e jurisprudencial.

A questão central é, portanto, formular uma reflexão uma releitura das normas que regulamentam o processo eleitoral brasileiro para fortalecer os postulados do regime democrático por meio da jurisdição eleitoral na resolução das disputas e conflitos experimentados em face de uma crescente intolerância que sinaliza avanço na contemporaneidade. A racionalidade jurídica precisa ser instada a se debruçar sobre as atuais ameaças e desafios da convivência social sob o regime democrático, a partir de uma lógica institucional de tolerância que garanta a manutenção das premissas que assentam a democracia. Daí por que se justifica, para esta pesquisa, a tentativa de investigar o papel da política e do Estado na coibição da intolerância no processo eleitoral brasileiro e como pode o Direito nessa seara interferir no aprimoramento da democracia. 


\section{CONCLUSÃO}

Depois de percorridas as premissas suscitadas nos capítulos desenvolvidos no curso desta investigação para enfrentar o problema central colocado, é preciso agora confrontar os resultados atingidos diante das hipóteses ventiladas no início desta pesquisa. Está evidenciado que o regime democrático não é um modelo institucional intocável e absoluto. Ao contrário, sua natural conflitualidade desperta uma fragilidade que exige permanente luta e crença nos seus fundamentos para assegurar sua manutenção e sobrevivência, cuja ameaça vem se desenvolvendo principalmente pela via eleitoral.

O povo é o protagonista do poder político na democracia, que, sob as mais diferentes variações, desperta arranjos institucionais que confluam em torno da multiplicidade de interesses, sentimentos, ambições, desejos e conflitos desse ator ficcional, cuja sobrevivência exige a tolerância com as diferenças como elemento fundamental, em uma perspectiva concreta e empírica da natureza humana. A filosofia de Espinosa demonstrou como seu conceito sobre os afetos humanos, baseado na tendência de preservar sua essência, encontra amparo nas premissas da neurobiologia, na medida em que explica os esforços conscientes e deliberados da autoconservação. Daí se funda o estado civil espinosiano que extrai da condição humana os fundamentos naturais do estado, ao invés de recorrer aos ensinamentos abstratos de uma natureza humana idealizada.

O esforço para autopreservação como primeiro fundamento da virtude não carrega uma conotação individualista, pois é apoiada por fatores biológicos que vinculam a necessidade de manter a si à necessidade de ajudar os outros a se manterem. O princípio ético fundamental da autopreservação depende da preocupação de preservar o outro. Por isso, a coletivização dos afetos individuais com os sociais é a tarefa da política, cujas instituições devem funcionar como termômetro para equilibrar o modo de ser dos indivíduos com a sociedade, buscando uma conformação da ordem da natureza com a ordem estatal.

A fundação institucional da liberdade e da convivência com base em uma dimensão radicalmente imanente, por meio de uma ética que se orienta pela lógica do que é útil ou prejudicial à preservação individual, que só se satisfaz em coletividade, é premissa para 
formação do Estado democrático, que decorre da potência da multidão, que, em Espinosa, equipara-se ao conceito de povo, ao contrário da distinção proposta pelas teorias contratualista com a passagem do estado de natureza para o estado civil. Assim, o Estado é a configuração ou modo da natureza, não sua negação. Essa concepção é fundamental para vislumbrar uma ordem civil capaz de coexistir com a "multidão", isto é, com a multiplicidade de afetos inerentes à natureza humana, que não negue as contradições e conflitos existentes no convívio em sociedade, para buscar mecanismos de convivência pacífica com base e por meio de suas diferenças, em vez de escondê-la por meio de fícções que não se materializam na realidade. O primeiro passo para compreender a tolerância como fundamento do regime democrático é reconhecer a conflitualidade própria da coletivização dos afetos como substância da potência da multidão para atingir o fim último da República, que, para Espinosa, é a liberdade em sua perspectiva de preservar na maior medida a existência que se esforça para se libertar do que lhe oprime o poder de agir e expandir seu bem estar.

No plano das discussões sobre formulações de teorias democráticas, segundo a ênfase no procedimento ou conteúdo do processo deliberativo, verificou-se a necessidade de coexistência de ambas as faces como medida de preservação da democracia. Não há antagonismo necessário no sistema político fundado na criação da ordem social pelos cidadãos e que assegure sua liberdade política no sentido de autodeterminação, que Kelsen denominou como princípio da tolerância. Ferrajoli condiciona a democracia política, que cuida das condições formais do exercício do poder, à validade substancial do Estado de Direito, que representa a dimensão social da democracia, na proteção não apenas dos interesses da maioria, mas o interesse de todos. Habermas também reconheceu uma zona de proteção à política deliberativa do processo democrático que impede que a consideração dos fins coletivos destrua a forma jurídica, de modo a diluir o direito em política.

Essa aparente dualidade reflete no grau de interferência judicial a ser admitido no processo político. $\mathrm{Na}$ realidade brasileira e países de capitalismo periférico, a desjuridificação da política favorece a perpetuação dos privilégios e desigualdades. Nesse cenário, a ordem jurídica se reveste não apenas do caráter regulatório das disputas sociais, mas também está imbuída de uma perspectiva finalística, transformadora, e dirigente, conforme explicaram Canotilho e Bercovici. 
A Constituição Federal de 1988 adotou um extenso rol de direitos e garantias fundamentais, que embasam o peso do substancialismo na democracia brasileira, fortalecendo o Poder Judiciário na físcalização e controle do processo político. Sem embargo, comprovou-se que, em ambas as acepções, jamais se refuta a existência de um núcleo básico de direitos fundamentais a ser garantido pelo Estado Democrático de Direito, unindo procedimentalistas e substancialistas na defesa da Constituição, da democracia e da efetivação dos direitos. Portanto, deve ser superado o falso antagonismo entre as correntes, ao mesmo tempo em que se evite incorrer em suas distorções patológicas que rompem o equilíbrio entre direito e política, pois importa, acima de tudo, a preservação da zona de interseção do ângulo formal e material da democracia, que é exatamente a garantia a proteção jurídica das minorias como expressão da tolerância.

A crítica de Karl Popper à filosofia de Platão oferece caminhos contra o pensamento totalitário que asfixia a expressão da individualidade na vida social. Para Popper, existem três exigência para uma teoria humanitária de justiça: o princípio igualitário, na perspectiva de abolir os privilégios naturais; o princípio geral do individualismo; e o princípio de que incumbe ao Estado proteger a liberdade dos cidadãos. Em Platão, cada uma dessas propostas se materializa de maneira oposta: o princípio do privilégio natural; o princípio geral do coletivismo; e o princípio segundo o qual é missão do indivíduo garantir a estabilidade do Estado. Bobbio evidenciou que o homem ocupa uma centralidade na democracia moderna em distinção à democracia dos antigos, como em Platão, que priorizava o caráter orgânico e subsidiou a formação do conceito político de povo, de modo que a soberania, na modernidade, é exercida por uma concepção individualista da sociedade.

Esse individualismo não suprime a dimensão social do homem nem considera o indivíduo apenas isoladamente no contexto social, pois distingue-se o individualismo de tradição liberal-libertária e o individualismo democrático, que agrupa o homem com outros indivíduos semelhantes e assim percebido por eles para formar uma associação de pessoas livres sem um viés orgânico. O primeiro conceito persegue a liberdade do indivíduo em relação à sociedade, ao passo que o segundo os reconcilia com base na livre vontade. Assim, descortina-se uma esfera de individualidade do cidadão intransponível à finalidade estatal, que não admite instrumentalização, expressa no núcleo da liberdade que se 
materializa como o direto de se autodeterminar sexualmente, religiosamente, filosoficamente, desde que o exercício dessa liberdade não ameaça outras liberdades.

Contra uma teoria da soberania que se ocupa em responder quem deve governar, Popper percebeu que essa preocupação carece da definição de controles do poder político, porquanto delimita o âmbito de suas reflexões para discutir quem seria dotado de mais discernimento e aptidão para exercer o poder. Esse deslocamento indevido do problema cria paradoxos para a democracia, que permitiriam o povo, no uso de sua liberdade, eleger um tirano. Assim, o exercício da liberdade sem nenhuma restrição resulta em uma limitação ainda maior do seu exercício, que recoloca o problema sob o ângulo do paradoxo da tolerância, que, em uma perspectiva jurídica, demonstra a contradição na necessidade de larga amplitude de proteção à liberdade de pensamento e autodeterminação em um contexto que essa garantia é utilizada para a defesa de ideias que advogam o fim dessa mesma liberdade indispensável para a democracia.

Portanto, não se pode tolerar a intolerância, pois o resultado da tolerância ilimitada é a eliminação dos tolerantes e, por conseguinte, da própria tolerância. Por isso, em nome da tolerância, deve ser proclamado o direito de não tolerar a intolerância e que sejam afastadas da legalidade democrática todas as expressões possíveis de sua manifestação. Não há meio termo no que diz respeito à convivência com a incitação à intolerância no ambiente democrático. Toda e qualquer forma de comportamento intolerante é incompatível com a ordem democrática, não estando protegido nem mesmo pela própria obrigação jurídica de tolerar as diferenças, em razão da necessidade de superação do paradoxo: caso se tolere juridicamente a defesa de ideias que apregoem a destruição da tolerância, é evidente que o êxito da intolerância importará na inexistência da tolerância.

A tolerância consiste, assim, na atribuição de igual valor a todas as pessoas, ao passo que a intolerância significa o desvalor associado a alguém em decorrência de sua particular identidade. No regime democrático, a tolerância, como desdobramento do princípio da igualdade formal, implica idêntica valoração a todas as identidades, sem qualquer distinção, em que igualdade e diferença se implicam mutuamente, pois todos devem ser tratados de maneira isonômica, a despeito de suas diferenças. No sentido material, todos devem ser considerados iguais, tanto quanto possível for, levando em conta suas posições social e economicamente desiguais. 
O respeito às diferenças, no plano da igualdade formal, opera para que a ordem jurídica não que coloque as diversidades étnicas, religiosas, culturais ou linguísticas, em situação de disparidade, preservando uma tolerância positiva à pluralidade das identidades humanas. As desigualdades se inserem no conteúdo da igualdade substancial, cuja consequência é a intolerância com as distintas realidades materiais como causa de privilégios ou discriminações sociais que lhes deformam a identidade. Essa é a vertente pela qual deve assentada a tolerância como fundamento da democracia decorrente da igualdade jurídica, tutelando o direito à tolerância das diferenças intrínsecas à diversidade humana e o direito à intolerância a desigualdades sociais e econômicas que subtraem condições materiais mínimas capazes de assegurar à pessoa a condição humana.

A Constituição Federal de 1988 representa o principal estatuto jurídico de tutela das minorias, que se definem tanto em termos quantitativos como qualitativos, pois se constituem como um grupo social numericamente inferior aos demais segmentos sociais e/ou, ainda que em maioria de membros, estão em situação de desvantagem social e marginalizados da participação nas políticas estatais. Tais desvantagens podem derivar de discriminações de ordem nacional, étnica, religiosa, cultural, linguística, sexual, que divergem daquela prevalecente na comunidade.

A luta pela afirmação de identidades coletivas impõe uma adequação da teoria do direito, fundada em termos individualistas, na afirmação do Estado Democrático de Direito. Para superar a aparente contradição da política de consideração das diferenças culturais e a política de universalização dos direitos subjetivos, ambas decorrentes do princípio do tratamento igual, Habermas explicitou como a autonomia privada não se divide da pública, o que resulta na necessidade de uma política de reconhecimento que também proteja a integridade do indivíduo nos contextos sociais que formam sua identidade. A proteção às minorias em sociedades multiculturais implica tanto o direito de cada cidadão crescer segundo seu padrão cultural de origem, quanto autoriza que seus filhos prossigam nele, ou afastem-se com indiferença ou por uma renúncia crítica, que lhes assegure formar sua identidade livremente com a ruptura da tradição, por meio de uma ordem jurídica que assegure que cada cultura regenere sua força.

Da disputa política entre maioria e minoria, nasce a institucionalização da oposição enquanto fenômeno político, cujo resultado é o temperamento do princípio da maioria, a fim de proteger o direito das minorias e assegurar a possibilidade de alternância do poder, que 
não se restringe à simples expectativa de rotatividade no âmbito parlamentar, mas, sobretudo, a alternância deve envolver as forças políticas extraparlamentares. Monica Caggiano constatou que, no campo da oposição, a tolerância no exercício do poder é um valor intocável para a preservação da democracia, assim como Manoel Gonçalves Ferreira Filho apontou a tolerância, ao lado dos elementos consensus e fairplay, como categorias indispensáveis à subsistência do regime.

Depois de analisar os reflexos da intolerância, a partir dos principais acontecimentos da equivocada condenação por espionagem do oficial judeu francês, Alfred Dreyfus, na França em 1894, enquanto precursor do antissemitismo que posteriormente se expandiu na Europa no século XX, revelou-se como a aposta na atuação formal das instituições para concretizar o conceito jacobino de uma nação baseada nos direitos humanos era completamente ingênua para salvar a república. A ruína da democracia francesa aconteceu com o aberto consentimento do povo, que, no final das contas, mobilizou-se não pela defesa da república, da justiça e da liberdade, mas contra seus antigos inimigos desde a Revolução: a aristocracia e o clero.

Há um encadeamento de fatores no contexto do caso Dreyfus na França que permite extrair aspectos na queda da República de Weimar, na Alemanha, e a consequente ascensão do Nacional Socialismo. Acima de tudo, houve uma contrarrevolução para minar as conquistas de recém conquistada democracia parlamentar e a plataforma de emancipação do trabalho, que sagrou-se vitoriosa, entre outros motivos, devido à estrutura da Constituição de 1919. Sem prejuízo da responsabilidade do Poder Legislativo, que não se preocupava em defender sua autoridade diante do Executivo, foi o Judiciário que ocupou o epicentro da contrarrevolução.

O Direito, notadamente por meio do Poder Judiciário, foi apropriado como estrutura do Estado para o movimento contrarrevolucionário alcançar o poder, o que foi demonstra pela conivência e parcialidade de diversos julgados, que fortaleciam politicamente as bandeiras do Nacional Socialismo, em detrimento dos partidários da democracia. A página escura da República Germânica representada pela justiça política custou a democracia daquele país, na medida em que o poder dos juízes crescia às custas do Parlamento.

A tolerância institucional com as forças antidemocráticas implodiu o contrato social no qual se fundava Weimar. A democracia alemã se suicidou e foi assinada ao mesmo 
tempo durante o processo político que levou à indicação de Hitler como chanceler. Apesar de inicialmente se apresentar como defensor da democracia e de suas instituições, Hitler não demorou para apresentar sua verdadeira face política com seus objetivos para destruí-la, cumprindo todas suas promessas. Seus nefastos propósitos deixaram de ser escondidos em comícios, na propaganda oficial do partido e mesmo perante os tribunais, mas que, ainda assim, continuava a ser empoderado pelos seus aliados na crença de que não haveria um sério risco ao país.

Mesmo com todos os sinais de alerta e depois de revelada toda a farsa que resultou no genocídio de 6 milhões de judeus, recentemente, o Tribunal Constitucional Federal alemão permitiu em janeiro de 2017 o registro do Partido Nacional Democrático da Alemanha, a despeito de sua manifesta proximidade ideológica com o Nacional Socialismo. A infeliz decisão concluiu perigosamente que, apesar de incompatível abstratamente com a ordem constitucional, somente seria possível proibir o registro do partido político se forem constatadas ações graves e concretas patrocinadas pelas siglas, na contramão do que ensinam os movimentos político e jurídico que resultam na ascensão de Hitler ao poder, que, paulatinamente, foi conquistando o poder.

Por isso, conclui-se que o Judiciário deve adotar uma postura de intransigência jurídica com toda e qualquer ameaça, concreta ou potencial, aos fundamentos democráticos, sob pena de as forças antidemocráticas se fortalecerem a ponto de serem capazes de paralisar e destruir a estruturas do Estado, que deveriam haver impedido sua progressão tempestivamente.

Por sua vez, a investigação da intolerância no cenário brasileiro remeteu como ponto de partida seu passado colonial, com base nas reflexões produzidas no âmbito do seminário Marx na Universidade de São Paulo. A metodologia adotada pelos seus pesquisadores, preocupados em ajustar as concepções marxistas à realidade local no oferecimento de uma proposta de compreensão de Brasil, voltava seus olhares para o que reputava ser o momento decisivo para a formação das instituições do país: o passado colonial.

Do sentido da colonização brasileira como empresa comercial destinada a explorar os recursos naturais em proveito do comércio europeu no contexto da transição do feudalismo para o capitalismo industrial como instrumento da acumulação primitiva de capital, forjou-se a organização da vida social, cuja principal marca é a escravidão. 
Diferentemente do modelo de escravidão conhecido no mundo antigo, o seu renascimento se explica como pura empreitada comercial, que privou a população negra de incorporar qualquer elemento construtivo na sociedade, pois dela apenas se exigiu sua força bruta e nenhuma humanidade.

Assim, aprofundou-se a distinção de raças no terreno nacional, criando um abismo entre as classes situadas nos extremos da escala social, dentre o qual se comprimia o que sobrou entre a minoria de senhores no topo da hierarquia e a multidão de escravos em sua base, isto é, a massa de deslocados sem ocupação certa em virtude do monopólio do trabalho pela escravidão. Esse modelo moldou uma sociedade violenta e consolidou uma desigualdade estrutural, conforme comprovaram diversas estatísticas apresentadas.

Esse segmento inorgânico de homens livres que se ajustavam em funções não absorvidas pela escravidão era ditado por lógica institucional do recurso à violência na resolução dos conflitos, como padrão de comportamento, em face de divergências e circunstâncias banais e não relacionais a valores altamente prezados que o justificasse. Uma cultura empobrecida e um sistema social que demandava relações de recíproca suplementação aumentou as oportunidades de conflito e radicalização de suas soluções. A violência se transmudou, assim, em conduta legítima, dada a inexistência de canais institucionais para o estabelecimento das compensações.

Assim como na escravidão, o princípio da dominação, que nasceu da relação de assistência econômica prestada pelo fazendeiro ao sitiante em troca de sua adesão política, aniquilou o predicado humano e a possibilidade de consciência das condições imediatas da existência social. Os assustadores índices da violência no Brasil comprovam uma violência endêmica, que, definitivamente, desmistificam qualquer narrativa romantizada da pacífica e amistosa inclusão cultural de todas as classes, etnias e raças. Na realidade, no Brasil, as diferenças transmudam-se em atributos de desqualificação.

Essa fenomenologia da violência e da intolerância repercute necessariamente na conformação do universo jurídico, na medida que, segundo advertia Oliveira Viana, não há como sobreviverem princípios liberais em uma sociedade parental, clânica e autoritária, uma vez compreendido o problema do direito no campo da culturologia aplicada. Diferentemente do método espanhola, que carregava traços comunitários, a colonização portuguesa, por meio do sistema de sesmarias individualistas ou particularistas, estimulava a dispersão da massa colonizadora, o que impediu a formação de laços de solidariedade, 
cooperação e colaboração em favor do bem público. Logo, ratifica-se que não se resolve o problema da democracia normativamente, mas por meio do fortalecimento concreto de instrumentos jurídicos capazes de aprimorar uma política democrática em face da intolerância e da violência historicamente arraigadas na formação brasileira, que, desde as manifestações de junho de 2013, recrudesceram-se.

O emblemático episódio na memória institucional brasileira que consistiu no julgamento do Habeas Corpus n. 84.242 pelo Supremo Tribunal Federal, impetrado por Siegfried Ellwanger, acusado de incitação à discriminação contra judeus, expôs perspectiva do aparato judicial brasileiro quanto à tratamento jurídico a ser despendido à intolerância. Por maioria, foi negada ordem e firmada a superação do conceito de raça só a ótica puramente biológica, uma vez que as pesquisas do genoma humano comprovaram que a única raça existente é a humana, motivo pelo qual o racismo se expressa juridicamente como fenômeno social e político.

Ao contrário do que decidiu o Tribunal Constitucional Federal alemão em 2017 quando da permissão do registro de partido com viés nazista, o STF coibiu a incitação ao racismo de forma veemente a fim de evitar que a disseminação de tais ideias venha a se constituir risco para a convivência pacífica no país. A importância na definição do racismo em sua maior amplitude, especialmente para efeito da cláusula constitucional da imprescritibilidade, justifica-se na necessidade de manter viva na memória do povo a permanente lembrança do passado sobre o presente, como medida a impedir que se reinaugurem ideologias inconciliáveis com os princípios democráticos.

Os votos divergentes confirmam que não é consensual no pensamento jurídico a extensão a ser dada ao combate à intolerância pela disseminação de ideias discriminatórias. Os fundamentos invocados pela divergência para conceder a ordem em favor do paciente aduziram a incidência da liberdade de expressão e, mais uma vez, o perigoso argumento de que não haveria um risco concreto e imediato de disruptura da ordem constitucional. Uma vez que foi demonstrado que a escalada da intolerância depende em grande medida do papel regulador do Poder Judiciário, a divergência no julgado deve manter em alerta a consciência jurídica contra a ameaça que ronda a proteção jurídica da tolerância, visto que seu processo de desintegração evolui por meio de um invisível agravamento para um cenário que costuma ser irreversível e fatal para a ordem democrática quando os Poderes constituídos não agem a tempo. 
Episódios recentes do desgaste da democracia liberal comprovados por movimentos políticos de confrontação do establishment político demonstraram que as ameaças ao regime democrático tem se desenvolvido de maneira sutil e quase imperceptível. Não mais por meio de golpes militares ou com a tomada violenta do poder, mas através de líderes eleitos. Há uma aparência de normalidade no funcionamento das instituições democráticas, que são colapsadas pelos governos eleitos pela perigosa via eleitoral.

Diante da ausência de um sinal claro do cruzamento da fronteira democrática, torna-se mais difícil estabelecer o momento de disparar os dispositivos de alarme da sociedade contra o paradoxo da democracia, que permite o sequestro do processo eletivo pelos seus futuros assassinos, que se utilizam de suas instituições para destruí-la. Nesse cinzento cenário de fragilização da democracia, um dos indicativos de sua potencial ameaça é a tolerância com a incitação à violência sob todas as formas, que deve ser combatida no âmbito do processo eleitoral brasileiro por intermédio de instrumentos jurídicos capazes de sancionar candidatos e partidos que flertem com a intolerância.

Daí por que a Justiça Eleitoral figura como protagonista na elevada missão de defender a democracia nesse campo. Desde a sua origem em 1932, essa justiça especializada demonstrou sua aptidão para romper com a ordem vigente do poder dos coronéis e a completa desmoralização das eleições. Na medida em que verificou na experiência histórica alemã a participação determinante do Judiciário para a ascensão do Nacional Socialismo, a jurisdição eleitoral representa um espaço institucional decisivo para conter a propagação da intolerância contra a democracia.

No regime jurídico dos partidos políticos, verificou-se que o respeito à tolerância como limite à fundação das legendas impõe-lhes a obrigação jurídica de resguardar o regime democrático, o pluripartidarismo, os direitos da pessoa humana e a defesa dos direitos fundamentais. Não obstante o texto constitucional lhes assegura relativa autonomia, conclui-se ser possível o controle judicial verticalizado pela Justiça Eleitoral de seu estatuto e dos atos partidários que denotem ameaça, ainda que potencial, ao regime democrático, sob pena de indeferimento do registro ou posterior cancelamento. pois não há democracia sem partidos democráticos,

Por sua vez, a propaganda eleitoral, enquanto principal ferramenta à disposição dos candidatos para a conquista do voto, é tutelada principalmente por representações eleitorais destinadas à suspensão da propaganda questionada e por meio dos pedidos de direito de 
resposta. Por traduzirem uma limitação da liberdade de expressão, que se reveste de particular relevância no curso do embate político, merece cautela a intervenção judicial destinada a restringir o debate eleitoral, que, por outro lado, deve guardar obediência aos postulados civilizatórios incompatíveis com a propagação da intolerância.

Como desdobramento do art. $3^{\circ}$, IV, da Constituição Federal, é vedada a propaganda eleitoral que veicule preconceitos de origem, raça, sexo, cor, idade e quaisquer outras formas de discriminação, na acepção mais larga de racismo em sua vertente social, conforme decidiu o Supremo Tribunal Federal no julgamento de Siegfried Ellwanger. Além da suspensão da propaganda irregular, assegura-se o direito de resposta ao candidato que for vítima de afirmação sabidamente inverídica, caluniosa, difamatória e injuriosa, que pode assumir conotação discriminatória, o que permite o combate a fake news que infestam o debate eleitoral com distorções e desqualificações grosseiras, embora se verifique uma atuação ainda tímida da Justiça Eleitoral.

$\mathrm{Na}$ selvageria do ambiente virtual costuma ser mais evidente ofensas com viés discriminatório do que no espaço institucional da propaganda sob responsabilidade dos atores políticos, que dispõem de sofisticadas estratégias e técnicas de marketing político para agir principalmente na esfera do inconsciente dos eleitores. A expressão da intolerância pode acontecer de maneira subliminar na propaganda eleitoral, obrigando a Justiça Eleitoral a estar atenta a toda a carga histórica e sociológica que impera nas relações de opressão que afligem a dignidade de determinados grupos sociais para manter a discussão ideológica entre os candidatos distante da apologia a preconceitos de toda natureza.

No sensível tema das inelegibilidades, a Lei da Ficha Limpa (Lei Complementar n. 135/2010) modificou a Lei Complementar n. 64/90, conferindo efetividade ao art. 14, parágrafo 9, da Constituição Federal de 1988, por meio da formulação de parâmetros objetivos de aferição da vida pregressa de potenciais candidatos que representem ameaça à probidade administrativa e à moralidade para o exercício do mandato, cujo compromisso com a tolerância se vislumbra inserido. Assim, apontou-se seu campo de proteção no art. $1^{\circ}$, I, “e”, 7, da Lei Complementar n. 64/90, que reputa inelegível quem for condenado, por decisão transitada em julgado ou por órgão judicial colegiado, desde a condenação até o transcurso do prazo de 8 anos após o cumprimento da pena, pelo crime de racismo.

Com base no entendimento do STF no julgamento de Siegfried Ellwanger, a expressão do racismo não deve se resumir à discriminação contra negros, mas deve ser 
compreendido em sua perspectiva social como diretriz interpretativa para garantir a máxima extensão de defesa da tolerância no processo eleitoral. Assim, afigura-se suficiente para a decretação da inelegibilidade a condenação em qualquer dos tipos penais previstos na Lei n. 7.716/88, que igualmente macula a moralidade para exercício do mandato eletivo considerada a vida pregressa do candidato.

Verificou-se que, apesar de existirem crimes eleitorais correlacionados com a tutela da tolerância que poderiam vir a atrair a inelegibilidade prevista no art. $1^{\circ}$, I, "e", 4, da Lei Complementar n. 64/90, a pequena pena estipulada pelo seu cometimento os torna delitos de menor potencial ofensivo, que os excetua da referida hipótese legal, por força do art. $1^{\circ}$, parágrafo $4^{\circ}$. Logo, constatou-se uma precária e deficiente criminalização dos delitos eleitorais relacionados à repressão da intolerância em matéria de inelegibilidade. Ainda que que outras hipóteses de inelegibilidade possam indiretamente se relacionarem a punições decorrentes de comportamentos discriminatórios, o art. 1', I, “e”, 4, da LC n. 64/90 é o único dispositivo que protege de maneira imediata a tolerância contra candidatos cuja vida pregressa indique potencial ameaça que os impeçam de participar do processo eleitoral.

Diferentemente de marcos teóricos que apostam no discernimento dos atores políticos para adotar estratégias que impeçam a ascensão de forças antidemocráticas, optouse por oferecer um incremento da atuação estatal, por meio da jurisdição eleitoral, como medida diminuir as vias de acesso ao poder pelos partidos políticos e candidatos que despertem sinais de alerta diante de sinalizações de intolerância. Essa perspectiva fundamentou uma releitura da amplitude do abuso de poder nas eleições para ajustá-lo à realidade que foi descrita na tentativa de conter as novas formas de deterioração da democracia pela via eleitoral, com o cuidado para não recorrer ao ativismo judicial de cunho autoritário na ingerência do embate eleitoral.

A legislação constitucional e infraconstitucional explicitou hipóteses de abuso de poder político, econômico e dos meios de comunicação. Contudo, o conceito de abuso de poder, interpretado conjuntamente com o plexo de normas que veda a incitação à intolerância no processo eleitoral, permitiu concluiu pela possibilidade de sua expressão na modalidade ideológica. Embora não se equipare à condição de agente público em sentido estrito, as estruturas de poder asseguradas pelo Estado ao candidato para desempenhar uma função revestida de interesse público, que é a disputa de um mandato eletivo, sujeitam-no à 
possibilidade de abusar de suas prerrogativas institucionais para, através delas, disseminar a intolerância no debate político.

Portanto, propôs-se uma nova dimensão do abuso de poder político, enquanto decorrente do poder da autoridade da candidatura, com ênfase no aspecto ideológico, que se denominou abuso de poder político, ou de autoridade, na dimensão ideológica, que não deve ser confundido ou equiparado a toda e qualquer infração às normas eleitorais que tutelem a tolerância. Observando todos os requisitos indispensáveis à consumação do abuso de poder para determinar a cassação do registro do candidato ou seu diploma, se eleito, o abuso de poder ideológico somente se caracterizará com aferição do critério quantitativo e qualitativo da gravidade das circunstâncias que o permeiam. Diante do novo horizonte conceitual oferecido na repressão da intolerância manifestada na disputa eleitoral, acreditase suprir uma lacuna na grade de proteção da tolerância que se justifica na necessidade de dotar o Poder Judiciário de ferramentas jurídicas necessárias para enfrentar a nova roupagem das ameaças ao regime democrático. 


\section{BIBLIOGRAFIA}

ACHEN, Christopher H; BARTELS, Larry M. Democracy for realists: why elections do not produce responsive government. New Jersey: Princeton University Press, 2016.

ALBRIGHT, Madeleine. Fascism: a warning. New York: Harper Collins Publishers, 2018.

ALEXY, Robert. Teoria dos direitos fundamentais. 2. ed. São Paulo: Malheiros, 2012.

ALMEIDA NETO, Manoel Carlos de. Direito eleitoral regulador. São Paulo: Revista dos Tribunais, 2014.

ALVIM, Frederico Franco. Abuso de poder nas competições eleitorais. Curitiba: Juruá, 2019.

ARENDT, Hannah. As origens do totalitarismo. Tradução Roberto Raposo São Paulo: Companhia das Letras, 2012.

ARENDT, Hannah. Eichmann em Jerusalém: um relato sobre a banalidade do mal. São Paulo: Companhia das Letras, 1999.

AURÉLIO, Diogo Pires. O mais natural dos regimes: Espinosa e a Democracia. Lisboa: Círculo de Leitores e Temas e Debates, 2014

ASSIS, Machado de. Quincas Borba. 3. ed. São Paulo: Moderna, 2016.

BAPTISTA, Fernando Pavan; FERRAZ, Anna Candida da Cunha. O Direito das Minorias na Constituição da República Federativa do Brasil de 1988. In: FERRAZ, Anna Candida da Cunha; BAPTISTA, Fernando Pavan; FREITAS, Riva Sobrado (Orgs.). Direito das minorias na América Latina e no Caribe: perspectiva convencional e jurídico-constitucional. Osasco: Edifieo, 2016.

BELLO, E.; BERCOVICI, G.; LIMA, M. M. B. O Fim das Ilusões Constitucionais de 1988?. Revista Direito e Práxis, Rio de Janeiro, v. 10, n.3, 2019, pp. 1769-1811.

BERCOVICI, Gilberto. Constituição Econômica e Desenvolvimento: uma leitura a partir da Constituição de 1988. Malheiros: São Paulo, 2005.

BOBBIO, Norberto. Teoria geral da política: a filosofia política e as lições dos clássicos. Tradução de Daniela Beccaccia Versiani. Rio de Janeiro: Campus, 2000.

BUNDESVERFASSUNGSGERICHT. Judment of the Second Senate of 17 January $2017 \quad-2$ BvB $1 / 13 \quad-$, paras. (1-1010). Disponível em: $<$ https://www.bundesverfassungsgericht.de/SharedDocs/Entscheidungen/EN/2017/01/bs20 170117_2bvb000113en.html> Acesso em 10 jul 2019. 
CAGGIANO, Monica Herman Salem. Direito parlamentar e direito eleitoral. Barueri: Manole, 2004.

CAGGIANO, Monica Herman Salem. Oposição na política: propostas para uma rearquitetura da democracia. São Paulo: Angelotti, 1995.

CAGGIANO, Monica Herman Salem. Ficha Limpa: impactos nos tribunais: tensões e confrontos. CAGGIANO, Monica Herman (org.). São Paulo. Revista dos Tribunais, 2014.

CAMPOS, Francisco. O estado nacional: sua estrutura, seu conteúdo ideológico. Brasília: Senado Federal, Conselho Editorial, 2001.

CANOTILHO, José Joaquim Gomes. Constituição dirigente e vinculação do legislador: contributo para a compreensão das normas constitucionais programáticas. Coimbra: Coimbra, 1994.

CASTAN, S. E. Holocausto: Judeu ou alemão. Porto Alegre: Revisão Editora Ltda, 1987.

CASTELLS, Manuel. Ruptura: a crise da democracia liberal. Tradução de Joana Angélica d'Avila Melo. Rio de Janeiro: Zahar, 2018.

CHAUÍ, Marilena. Política em Espinoza. São Paulo: Companhia das Letras, 2003.

CONEGLIAN, Olivar Augusto Roberti. Inelegibilidade: inelegibilidade e proporcionalidade, inelegibilidade e abuso de poder. Curitiba: Juruá, 2009.

DAHL, Robert. How democratic is the american constitution? 2. ed. Yale: Yale University Press, 2003.

DAHL, Robert A. Poliarquia: participação e oposição. Tradução de Celso Mauro Paciornik. São Paulo: Universidade de São Paulo, 2005.

DAMÁSIO, Antônio. Em busca de Espinosa: prazer e dor na ciência dos sentimentos. São Paulo: Companhia das Letras, 2004.

DENNINGER, Erhard. "Security, diversity, solidarity" instead of "freedom, equality, fraternity". Constellations, v. 7, n. 4. Oxford: Blackwell Publishers Ltd., 2000, p. 507-521.

DWORKIN, Ronald. Is democracy possible here?: principles for a new political debate. Princeton: Princeton University Press, 2008.

ELY, John Hart. Democracia e Desconfiança: uma teoria do controle judicial de constitucionalidade. São Paulo: WMF Martins Fontes, 2010.

ESPINOSA, Baruch de. Breve Tratado de Deus, do homem e seu bem-estar. Belo Horizonte: São Paulo: Autêntica, 2012.

ESPINOSA, Baruch de. Tratado Político. Tradução Diogo Pires Aurélio. São Paulo: WMF Martins Fontes, 2009. 
ESPINOSA, Baruch de. Tratado Teológico-Político. Tradução de Diogo Pires Aurélio. 3. ed. Lisboa: Imprensa Nacional-Casa da Moeda, 2004.

FAORO, Raymundo. Os donos do poder: formação do patronato político brasileiro. 4. ed. São Paulo: Globo, 2008, p. 708.

FERRAJOLI, Luigi. Direito e Razão: teoria do garantismo penal. São Paulo: Revista dos Tribunais, 2014.

FERRAZ, Ana Candida da Cunha; BAPTISTA, Fernando Pavan; FREITAS, Riva Sobrado (Orgs.). Direito das minorias na América Latina e no Caribe: perspectiva convencional e jurídico-constitucional. Osasco: Edifieo, 2016.

FERREIRA FILHO, Manoel Gonçalves. A democracia possível. São Paulo: Saraiva, 1972.

FISCHER, Kuno; LAND, J.; VAUGHAN, Charles Edwyn; BRUNSCHVICG, Léon. Estudos sobre Spinoza. Rio de Janeiro: Contraponto, 2014.

FRAENKEL, Ernst. The dual state: a contribution of the theory of dictatorship. New York: Oxford University Press, 2017.

FRANCO, Maria Sylvia de Carvalho. Homens livres na ordem escravocrata. São Paulo: UNESP, 1997.

GOETHE, Johann Wolfgang von. Fausto. Tradução de Agostinho D’Ornellas. São Paulo: Martin Claret, 2016.

GOMES, José Jairo. Direito Eleitoral. 8. ed. São Paulo: Atlas, 2012.

GUIMARAENS, Francisco de. Direito, ética e política em Spinoza: uma cartografia da imanência. 2. ed. Rio de Janeiro: Lumen Juris, 2011.

HABERMAS, Jürgen. A inclusão do outro: estudos de teoria política. Traduzido por Denilson Luís Werle. São Paulo: UNESP, 2018.

HABERMAS, Jürgen. Direito e democracia: entre facticidade e validade. Volume I e II. 2. ed. Rio de Janeiro: 2012.

HAURIOU, Maurice; GICQUEL, Jean; GÉLARD, Patrice. Droit Constitutionnel et Institutions Politiques. Paris: Montchrestien, 1975.

HOBBES, Thomas. Leviatã: ou material, forma e poder de um estado eclesiástico e civil. 2. ed. São Paulo: Martin Claret, 2008.

Fontes, 2010.

Os elementos da lei natural e política. São Paulo: WMF Martins

HOLLAND, Tom. Fogo persa. Rio de Janeiro: Record, 2008.

Homero. Odisseia. São Paulo: Editora 34, 2014. 
HUNTINGTON, Samuel P. A terceira onda: a democratização do século XX. Tradução de Sergio Gois de Paula. Ática: São Paulo, 1994.

ISRAEL'S CONSTITUTION OF 1958 WITH AMENDMENTS THROUGH 2013. Disponível em: <https://www.constituteproject.org/constitution/Israel_2013.pdf?lang=en>. Acesso em: 7 janeiro de 2010.

KANT, Immanuel. Fundamentos da Metafísica dos Costumes, in: Os pensadores Kant (II). Tradução de Paulo Quintela. São Paulo: Abril Cultural, 1980, p. 103-162.

KELSEN, Hans. A democracia. Tradução de Vera Barkow, Jeffeerson Luiz Camargo, Marcelo Brandão Cipolla e Ivone Castilho Benedetti. São Paulo: Martin Fontes, 2000 .

LAFER, C. Hannah Arendt: pensamento, persuasão e poder. 3. ed. Rio de Janeiro/São Paulo: Paz e Terra, 2018.

LAFER, C. Parecer. O caso Ellwanger: Anti-semitismo como crime da prática do racismo. (Estudos em homenagem a Anna Maria Villela). Revista de Informação Legislativa, v. 162, p. 53-89, 2004.

LEITÃO, Valton de Miranda. O inimigo necessário: a paranoia em Carl Schmitt. São Paulo: Intermeios, 2015.

LEMBO, Cláudio. A pessoa: seus direitos. Barueri: São Paulo, 2007.

LEMBO, Cláudio. Cronologia básica do Direito Eleitoral Brasileiro. In: LEMBO, Cláudio; CAGGIANO, Monica Herman Salem (Org.). O Voto nas Américas. Barueri: Minha Editora, São Paulo: Cepes, 2008, pp. 73-106.

LEMBO, Cláudio. Visões do cotidiano. Barueri: Manole, 2012.

LEVITSKY, Steven; ZIBLATT, Daniel. Como morrem as democracias. Rio de Janeiro: Zahar, 2018.

LIMA, Martonio Mont'Alverne Barreto. O Tribunal Federal Constitucional alemão $\mathrm{e}$ a infeliz decisão sobre o NPD. Disponível em: < https://www.conjur.com.br/2017-jan-18/martonio-lima-infeliz-decisao-tribunalconstitucional-alemao $>$ Acesso em 10 jul 2019.

LIMA, Martonio Mont'Alverne Barreto; LEITÃO, Rômulo Guilherme; CHAVES, Daniel Rocha. Risco de sempre: Poder Judiciário na democracia. In: LIMA, Martonio Mont'Alverne Barreto; CARMO, Valter Moura do; COUTINHO, Júlia Maia Meneses de. (Orgs.). Progresso e Regresso político: a democracia em risco. Rio da Janeiro: Lumen Juris, 2017, pp. 327-338.

LINCOLN, Abraham. Lincoln's Gettysburg address at the National Cemetery at Gettysburg, Pennsylvania. Disponível em Library of Congress: 
$<$ https://cdn.loc.gov/service/rbc/lprbscsm/scsm0365/scsm0365.pdf. $10 / 01 / 2020>$.

LOCKE, John. Segundo tratado sobre o governo: ensaio relativo à verdadeira origem, extensão e objetivo do governo civil. São Paulo: Martin Claret, 2006.

MACHADO, Raquel. Direito Eleitoral. São Paulo: Atlas, 2016.

MAQUIAVEL, Nicolau. Discursos sobre a primeira década de Tito Lívio. São Paulo: Martins Fontes, 2007.

MARLMEINSTEIN, George. Críticas à Teoria das Gerações (ou mesmo dimensões) dos direitos fundamentais. n. 3, ano 2. Revista Opinião Jurídica. 2004.1.

MARX, Karl. Manuscritos econômico-filosóficos. São Paulo: Boitempo, 2010.

MAUS, Ingeborg. O Judiciário como superego da sociedade: o papel da atividade jurisprudencial na "sociedade órfâ". Trad. Martonio Lima e Paulo Albuquerque. Revista Novos Estudos CEBRAP, no 58, nov. de 2000.

MEZZAROBA, Orides. Introdução ao direito partidário brasileiro. 2. ed. Rio de Janeiro: Lumen Juris, 2004.

MONTESQUIEU, Charles de Secondat. Do espírito das leis. Tradução de Roberto Leal Ferreira. São Paulo: Martin Claret, 2010.

NEUMANN, Franz. Behemoth: the structure and practice of national socialism 1933-1944. Chicago: Oxford Publish Press in association with the United States holocaust memorial museum, 2009.

NEUMANN, Franz. The decay of german democracy. The political quarterly, volume 4, N. 4, 1933. p. 525-543.

NOVAIS, Fernando A. Caio Prado Júnior Historiador. Novos Estudos Cebrap, São Paulo, v. 2, 2, p. 66-70, jul. 83.

. Portugal e Brasil na Crise do Antigo Sistema Colonial (1777-1808). 2. ed. São Paulo: Editora HUCITEC, 1983.

POPPER, Karl Raimund. A sociedade aberta e seus inimigos. Tradução de Milton Amado. Belo Horizonte: Itatiaia. São Paulo: Universidade de São Paulo, 1987.

PRADO JÚNIOR, Caio. Formação do Brasil contemporâneo: colônia. São Paulo: Companhia das Letras, 2011.

RAMOS, Elival da Silva. Ativismo Judicial: parâmetros dogmáticos. São Paulo: Saraiva, 2010.

RANCIÈRE, Jacques. O ódio à democracia. São Paulo: Boitempo, 2014.

RAWLS, John. Uma teoria da justiça. Tradução de Jussara Simões. 3. ed. São Paulo: Martins Fontes, 2008. 
RICUPERO, Bernardo. Caio Prado Jr. e a nacionalização do marxismo. ed. 34. São Paulo: Departamento de Ciência Política da Universidade de São Paulo, 2000.

RIZEK, Fernanda Montenegro de Menezes; JUNIOR, Rubens Naman Rizek. Marketing Político X Legislação Eleitoral. In: CAGGIANO, Monica Herman Salem; MESSA, Ana Flávia; ALMEIDA, Fernanda Dias Menezes de. (Orgs.). Direito Eleitoral em debate: estudos em homenagem a Cláudio Lembo. São Paulo: Saraiva: 2013, pp. 141-166.

RODRIGUES, Lidiane Soares. A produção social do marxismo em São Paulo (1958-1978): mestres, discípulos e 'Um seminário'. Tese de Doutorado. São Paulo: FFLCH-USP. 2011.

ROUSSEAU, Jean-Jacques. Do contrato social ou princípios do direito político. São Paulo: Martin Claret, 2007.

SARLET, Ingo Wolfgang. Dignidade da pessoa humana e direitos fundamentais na Constituição Federal de 1988. 7. ed. Porto Alegre: Livraria do Advogado, 2009.

SCHWARCZ, Lilian Moritz. Sobre o autoritarismo brasileiro. São Paulo: Companhia das Letras, 2019.

SCHWARZ, Roberto. Ao vencedor as batatas. Forma literária e processo social nos inícios do romance brasileiro. 4. ed. São Paulo: Livraria Duas Cidades, 1992, p. 15

SCHWARZ, Roberto. Seqüências brasileiras: ensaios. São Paulo: Companhia das Letras, 1999.

SHAKESPEARE, William. O mercador de Veneza. 2. ed. São Paulo: Martin Claret, 2013.

SCHMITT, C. O conceito do político. Tradução de Álvaro L. M. Valls. Petrópolis: Vozes, 1992.

SCHMITT, Carl. The dictatorship of the Reich president according to Art 48 of the Reich constitution. Constellations, volume 18, N. 3, 2011. Blackwell Publishers Ltda, 2011, p. 299-323.

SPINOZA, Benedictus de. Ética. Tradução de Tomaz Tadeu. 3. ed. Belo Horizonte: Autêntica, 2013.

STRECK, Lenio. Verdade e Consenso: constituição, hermenêutica e teorias discursivas. 4. ed. São Paulo: Saraiva, 2011.

TSE. Cancelamento de Partido n. 411/RJ. Rel. Min. Francisco Sá Filho. Boletim eleitoral, Volume 233, Tomo 1, Página 365.

VELLOSO, AGRA. Elementos de direito eleitoral. São Paulo: Saraiva, 2009.

VIANA, Oliveira. Instituições políticas brasileiras. Brasília: Conselho Editorial do Senado Federal, 1999. 
XEREZ, A.G.S. Fidelidade partidária e tempo mínimo de filiação como condição de elegibilidade. In: CAGGIANO, Monica Herman Salem. (Org.). Reforma política: um mito inacabado. Barueri: Manole, 2017, p. 112-137.

XEREZ, A. G. S; KOMATA, Nicanor Barry. O comportamento eleitoral e as perspectivas da democracia representativa. In: LEMBO, Claudio; PINTO, Felipe Chiarello de Sousa. (Orgs.). Direito constitucional político-eleitoral: estudos em homenagem à Profa. Dra. Monica Herman Salem Caggiano. Belo Horizonte: Arraes, 2017, pp. 96-108.

XEREZ, A. G. S. Tribunais de contas e inelegibilidade: limites da jurisdição eleitoral. 1. ed. Rio de Janeiro: Lumen Juris, 2015 